\title{
Skafoid kırıkları
}

\author{
Scaphoid fractures
}

\author{
Kahraman Öztürk
}

Baltalimanı Kemik Hastalıkları Eğitim ve Araştırma Hastanesi, El Cerrahisi Kliniği, İstanbul

\begin{abstract}
Skafoid üst ekstremitede radius, alt uçtan sonra en fazla kırılan karpal kemiktir. Skafoid kırıkları, açık el üzerine düşme sonucu, aktif ve genç erkeklerde daha sık görülmektedir. Erken teşhis ve uygun tedavi ile yüksek kaynama oranları elde edilmektedir. Tedavi edilmeyen skafoid kırıklarında, kaynamama, hörgüç (humpback) deformitesi, avasküler nekroz, karpal kemiklerde çökme meydana gelir. Kaynamayan skafoid kırıkları, uzun vadede el bileği artriti ile sonlanmaktadır. Kayma olmayan stabil veya kırık hattı tamamlanmamış kırıklar alçı tespiti ile tedavi edilebilir. Uzun tespit süresinin getireceği sakıncalardan kaçınmak için, kaynama oluncaya kadar optimal stabilizasyon sağlayan ve çok az yumuşak doku yaralanması ile birlikte olan ya da artroskopi yardımlı perkütan veya açık cerrahi teknikler gittikçe daha çok uygulanmaktadır.
\end{abstract}

Anahtar sözcükler: kırıklar, skafoid kemik; tıbbi görüntüleme; konservatif tedavi; cerrahi tedavi; kanüllü vida
Scaphoid is the second most frequently broken carpal bone in the upper extremity following distal radius. Scaphoid fractures occur more often in active and young males due to a fall on outstretched hand. A high union rate is obtained with early diagnosis and proper treatment. Nonunion, humpback deformity, avascular necrosis, collapse in carpal bones are the consequences of untreated scaphoid fractures. Long term scaphoid fracture nonunions end up with wrist arthritis. Nondisplaced stable or incomplete fractures can be treated with plaster immobilization. To avoid harm related to long term immobilization, percutaneous or arthroscopically assisted percutaneous techniques or open surgical techniques providing optimal stabilization until union and with little soft tissue injury are applied more frequently.

Key words: fractures, scaphoid bone; medical imaging; conservative treatment; surgical treatment; cannulated screw

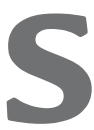
kafoidin karpal kemikler içinde kırılma sıklığı \%70'tir. ${ }^{[1]}$ Skafoid kırıkları sıklıkla dışa açılmış el üzerine düşme ya da el bileğinin dorsifleksiyona zorlandığı yaralanmalar neticesi görülür. ${ }^{[1-3]}$ Öyküde önemsiz bir travmaya eşlik eden kaymamış skafoid kırı̆ıında radyografiler negatif olduğunda, yaralanma sıklıkla burkulma teşhisi konularak atlanabilir. ${ }^{[4]}$ Yüksekten düşme ya da motorlu araç kazası gibi yüksek enerjili yaralanmalarda da skafoid kırı̆gı görülebileceği akılda tutulmalıdır.

Skafoid kırıkları en sık genç yaş grubu ve erkeklerde görülür. ${ }^{[5]}$ Tassel, epidemiyolojik çalışmada insidansı 1000 kişi - yılda 1,21 , yaş grubunu ise $20-24$ yaş olarak bildirmiştir. ${ }^{[6]}$

\section{ANATOMI}

El bileği proksimal sırasındaki skafoidin geometrik yapısı çok karmaşık üç boyutludur. Proksimal, distal ve mediyal yüzlerinin tamamı yanı sıra, lateral kısmının yarısı da eklem kıkırdağıyla kaplıdır. Skafoid, anatomik olarak proksimal kutup, bel ve distal kutup (tüberkül) olarak ayrılır. Skafoidin kan akımı desteği çok narindir; kırık olduğunda bu akım kesintiye uğrayarak iyileşmeyi engelleyebilir. ${ }^{[4,7]}$ Skafoid kırıklarının \%13-50'sinde avasküler nekroz görülebilir. ${ }^{[4,8]}$ Skafoidin arteryel beslenmesinin \%70-80'i radyal arterden gelen ve dorsalden kemiğe giren damardan sağlanır. Takiben dallara ayrılarak proksimale ve distale uzanır. Kalan \%20-30'luk kısım volarden direkt radyal arterden ya

- İletişim adresi: Dr. Kahraman Öztürk, Baltalimanı Kemik Hastalıkları Eğitim ve Araştırma Hastanesi, El Cerrahisi Kliniği, İstanbul Tel: 0212 - 3237075,0532 - 4271798 e-posta: kahraman_ozturk@hotmail.com

- Geliș tarihi: 25 Șubat 2014 Kabul tarihi: 25 Șubat 2014 
da yüzeyel palmar arter dalından kaynaklanıp skafoidin distal palmar bölgesine ulaşan dallardan beslenir. Proksimal kutbun beslenmesi direkt olarak kemik içi kan dolaşımından retrograd yolla oluşur. ${ }^{[9,10]}$

\section{KLINIK TANI}

Çoğu hastada anatomik enfiye çukurunda, skafoidin distal çıkıntısında ya da dorsalde proksimal kutup üzerinde ağrı olabildiği gibi, başparmağın düz traksiyonu ve el bileğinin özellikle fleksiyon ve radyal deviyasyon hareketinin sonlandığı sınırda da ağrı görülebilir. Diğer klinik bulgular; krepitasyon, ödem nedeniyle enfiye çukuru konkavitesinde azalma ve ekimozdur. Klinik muayenenin duyarlılı̆̆ı yüksektir ancak özgüllüğü \%74-80 kadardır. El bileğinde radyoulnar eklem ve dirsek mutlaka muayene edilmelidir. ${ }^{[11-13]}$

\section{RADYOLOJiK DEĞERLENDIRME}

Skafoid kırık şüphesinde standart arka-ön, ulnar deviyasyonda arka-ön, lateral ve oblik $\left(45^{\circ}\right.$ pronasyon ve supinasyonda) radyografiler istenir (Şekil 1 a,b,e,f). [7,14] Arka-ön grafilerde el bileğinin ulnar deviyasyona alınması skafoidi ekstansiyona zorlayarak normal dizilim ve mimari yapısının görülmesinde yarar sağlar. Distal kutup, orta $1 / 3^{\prime} l u ̈ k$ kısım ve bel bölgesi en iyi $45^{\circ}$ pronasyonda oblik grafide değerlendirilebilir. Dorsal kenar ise $45^{\circ}$ supinasyonda oblik röntgende daha iyi görülür. Yumruk pozisyonunda skafoid grafisi, klinik şüphe olduğunda skafolunat yaralanmayı saptama açısından yararlıdır. Klinik bulguları olan, radyografileri negatif olan hastalar iki haftalık alçılamayı takiben muayene ve radyografi tekrarı ile değerlendirilmelidir. Kırık hattındaki kemik dokuda rezorpsiyon kırı̆ıı görünür hale gelmesine neden olur. Ancak hızlı teşhis, gereksiz alçılama ve ekonomik kaybı önlemek için bu uygulama yeterli değildir. Kırık şüphesinde ultrasonografi, sintigrafi, bilgisayarlı tomografi (BT) ve manyetik rezonans (MR) görüntüleme tetkikleri kullanılabilir. ${ }^{[15]}$ MR'da görülen kemik ödeminin ve BT'deki küçük unikortikal çizgilerin gerçek bir kırığı gösterip göstermediği ise halen açık değildir. ${ }^{[16]}$

BT ile, skafoid kırıklarında tanı, translasyon, parçalanma ve "hörgüç" (humpback) deformitesi tespiti yanında, kaynama yokluğu ya da kaynama gecikmesi riskinin yüksek olduğu durumlar saptanarak, gereksiz uzamış alçı tedavisi ve tekrarlayıcı radyolojik incelemelerden kaçınılabilir (Şekil $1 \mathrm{~g}, \mathrm{~h}$ ). ${ }^{[17]}$ BT, skafoidin uzun ekseni planında çekilmelidir. Uygun sagittal plan taraması için, hasta yüzüstü yatar pozisyonunda iken eli başının üzerinde, ön kol tam pronasyonda ve el bileği nötral pozisyonda tutulmalı, başparmak tam abduksiyonda iken başparmak metakarpı ekseninde tarama yapılmalıdır. Koronal plan görüntüleri için, ön kol nötral planda tutulmalı ve 1 mm'lik ince kesitler alınmalıdır. ${ }^{[7]}$ Mallee, skafoid kırık şüphesinde duyarlılık, özgüllük ve güvenilirliği, BT için sırasıyla $\% 67, \% 96, \% 91$ ve MR için de sırasıyla $\% 67, \% 89$ ve $\% 85$ bulmuştur. Şüpheli skafoid kırıkları için, skafoidin uzun ekseniyle tanımlanmış düzlemlerde rekonstrükte edilmiş BT ile MR kıyaslanabilir. ${ }^{16]}$

Kemik taraması duyarlıdır ancak özgün değildir. İlk 24 saatte skafoid alanında artmış tutulum gösterir. Muayeneyle uyumlu fokal artmış aktivite, akut bir kırığı gösterir.

MR, skafoid kırığını ilk 4-6 saatte saptayabilir. ${ }^{[4]}$ Proksimal kutbun vaskülaritesi MR ile değerlendirilmelidir. MR'de kontrast tutmama avaskülariteyi gösterir. Akut kırıklar düşük T1 ve yüksek T2 sinyal yoğunluğu gösterirken (Şekil 1c, d), kaynama yokluğu ya da beslenme bozukluğunda düşük T1 ve T2 sinyali alınır. ${ }^{[14]}$ MR, şüpheli skafoid kırıklarını ayırmada duyarlılığı \%98, özgüllügü \%99 ve güvenirliliği \%96 olması ile halen en iyi radyolojik yöntemdir. ${ }^{[15]}$ Bu testlerin tümü kesinlikle kırığı göstermekten çok kırığı dışlamakta daha iyidir.[14-16]

\section{SKAFOID KIRIKLARININ BIYOMEKANIĞi}

El bileğinin ekstansiyon hareketi yaklaşık olarak $85^{\circ}$ 'dir. ${ }^{[18]}$ Aktif olarak yapılan $60^{\circ}$ el bileği ekstansiyon hareketinde skafoid kapitatum ile yaklaşık olarak aynı miktarda ekstansiyona gelir. ${ }^{[19]}$ Rainbow ve arkadaşlarının yaptıkları çalışmada, $90^{\circ}$ el bilek ekstansiyonu esnasında skafoid kemiğin kapitatuma göre bu harekete katılımı \%74 olarak bulunmuştur ve bu da palmar taraftaki kuvvetli karpal bağların engellemesine bağlanmıştır. ${ }^{[20]}$ Dorsifleksiyonun $95-100^{\circ}$ olduğu anda aşırı yüklenme ile skafoid kemik palmar yönde zorlanır, ancak proksimal kutbu bağlar tarafindan güçlü bir şekilde stabilize edilir. Kapsüler yapılar tarafından desteklenmeyen distal kutba yük biner ve eğilme momentine karşı koyamayan bel bölgesinde kırık oluşur. ${ }^{[21]} \mathrm{Bu}$ mekanizmanın klinik karşılığı ise açık el bileği üzerine düşmektir. El bileği nötral veya hafif derecede fleksiyonda iken yumruk atan bir kişide, yük sadece ikinci metakarp ile iletildiğinde, aksiyel yüklenmenin de skafoid kırığına yol açabildiği gösterilmiştir. ${ }^{[22]}$ Bükücü, makaslayıcı ve translasyonel güçlerin etkisi altında kalan skafoide tespit uygulanmaz ise kırık parçalar kayma eğiliminde olur. Distal parça fleksiyona giderken, proksimal parça sağlam skafolunat interosseöz bağ sayesinde, lunat kemik ile birlikte ekstansiyona gelir. Bu durum dorsal interkalar segment instabilitesi (DISI) olarak bilinir. Distal parçanın fleksiyona gitmesinde trapezium-skafoid makaslama stresi, eklemin kompresif gücü ve kapitolunat rotasyon rol oynar. Sonuç olarak skafoid kırık hattının 

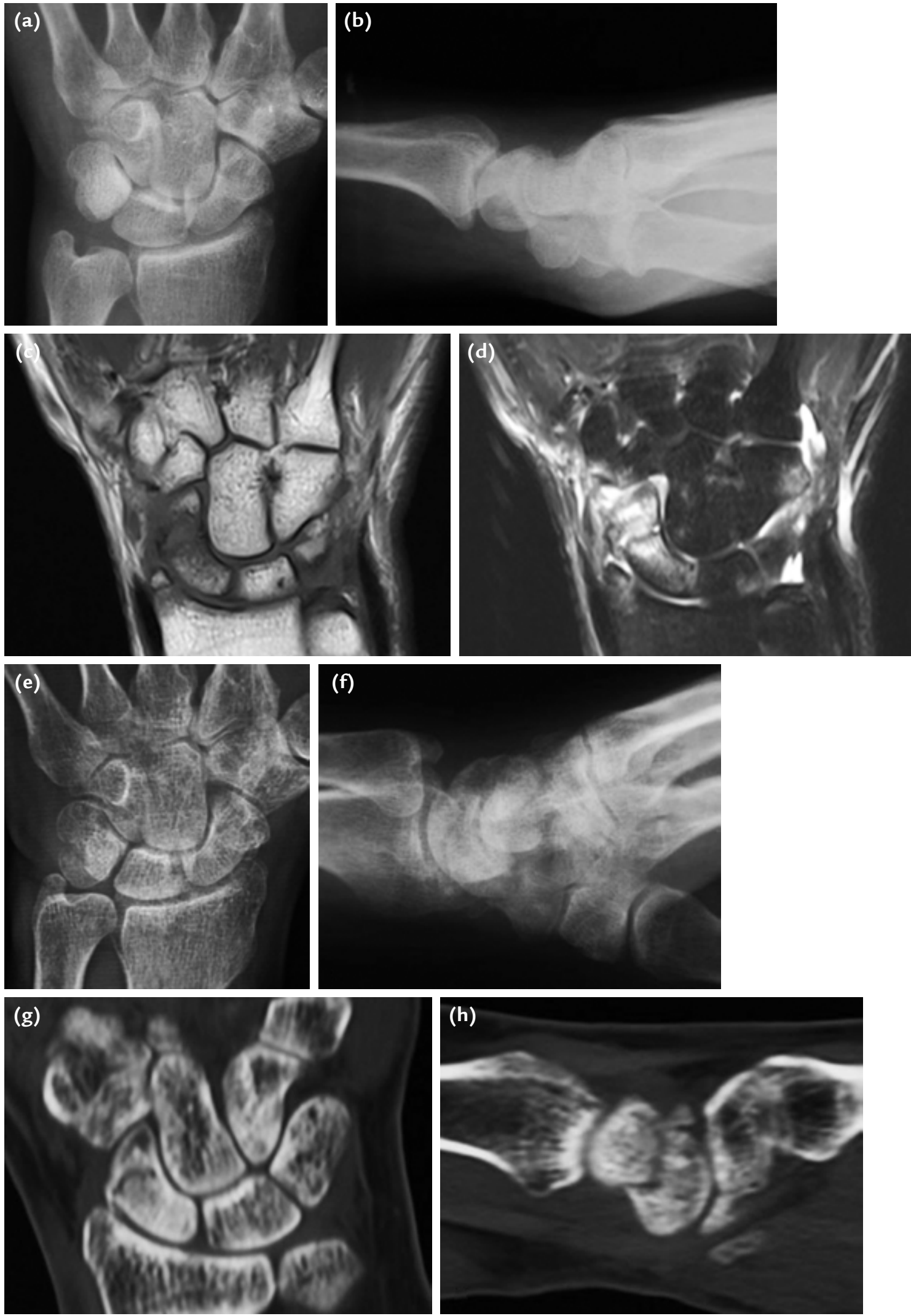

Şekil 1. a-h. Sol skafoid kırığının; arka-ön ve yan radyografik görüntüsü (a, b), MR'de düşük T1 ve yüksek T2 sinyal yoğunluğu görüntüsü (c, d), 1 ay sonra kırık hattında rezorpsiyon sonrası arka-ön ve $45^{\circ}$ pronasyonda oblik radyografide kırık hattının radyolojik görüntüsü (e, f) ve BT'de, koronal kesitte kırık hattı, yan kesitte hörgüç deformitesi ve dorsalde parçalanma görüntüleri (g, h). 


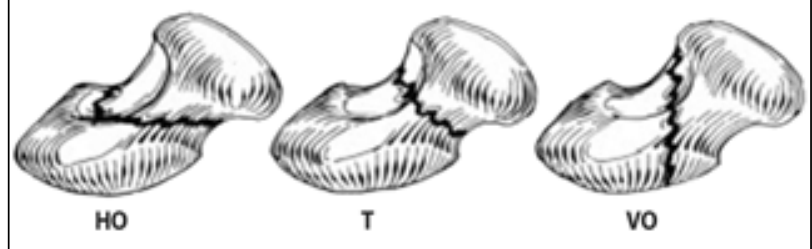

Şekil 2. Skafoid kırıklarında Russe sınıflaması (VO, vertikal oblik; T, transvers; HO, horizontal oblik). ${ }^{[2]}$

dorsalinde açılma olur ve "hörgüç" deformitesi adı verilen açılanma oluşur. ${ }^{[23]}$

\section{KIRIK SINIFLANDIRMASI}

Skafoid kırıklarının \%70'i bel, \%10-20'si distal kutup, $\% 5$ 'i tüberkül ve \%5’i proksimal kutupta meydana gelir. Skafoid kırıkları, stabilite, kırık yerleşimi, kırık planı ve osteonekrozun varlığına göre sınıflandııımıştır. ${ }^{[2,24]}$ Otto Russe, skafoid kırıklarını şekline göre, horizontal oblik, transvers ve vertikal oblik olarak üçe ayırmış (Şekil 2) ve oblik kırıkların stabil olmadıklarını 1960 yılında vurgulamıştır. ${ }^{[2]}$ Herbert ve Fisher 1984 yılında skafoid kırıklarının cerrahi tedavisinde kullanılmak üzere geliştirdikleri kompresyon vidasını tanımlarken, aynı zamanda röntgen görüntülerine dayanarak da bir sınıflama tanımlamışlardır (Tablo 1). ${ }^{[3]}$ Akut kırıklar, Tip A akut stabil kırık, Tip B stabil olmayan akut kırık olarak ayrılmıştır. Tip C kırıklar altı hafta alçıyla immobilizasyondan sonra kaynamada gecikme gösterirlerken, Tip D kırıklar belirgin kaynamamadır (Şekil 3). Yazarlar, Tip A kırıkların alçı tespiti ile tedavi edilebileceğini vurgulamışlardır. Bu sınıflamaların distal kutbu içermediğini düşünen Prosser ve arkadaşları, 1988'de sadece distal kutup kırıklarına yönelik bir sınıflama tanımlamışlardır (Tip 1, tüberositasın avulsiyon kırığı veya fissürü; Tip 2, distal kutbun ekleme uzanan kırığı [a, radyal taraf; b, ulnar taraf; c, her ikisi birden] ve Tip 3 , distal eklem yüzünün kapitatuma bakan tarafında osteokondral parça) (Şekil 4). ${ }^{[25]}$ Compson, 1998'de direkt grafi ile bu sınıflamaları yapmanın zorluğunu vurgulamış ve Tip 1, cerrahi bel (transvers); Tip 2,

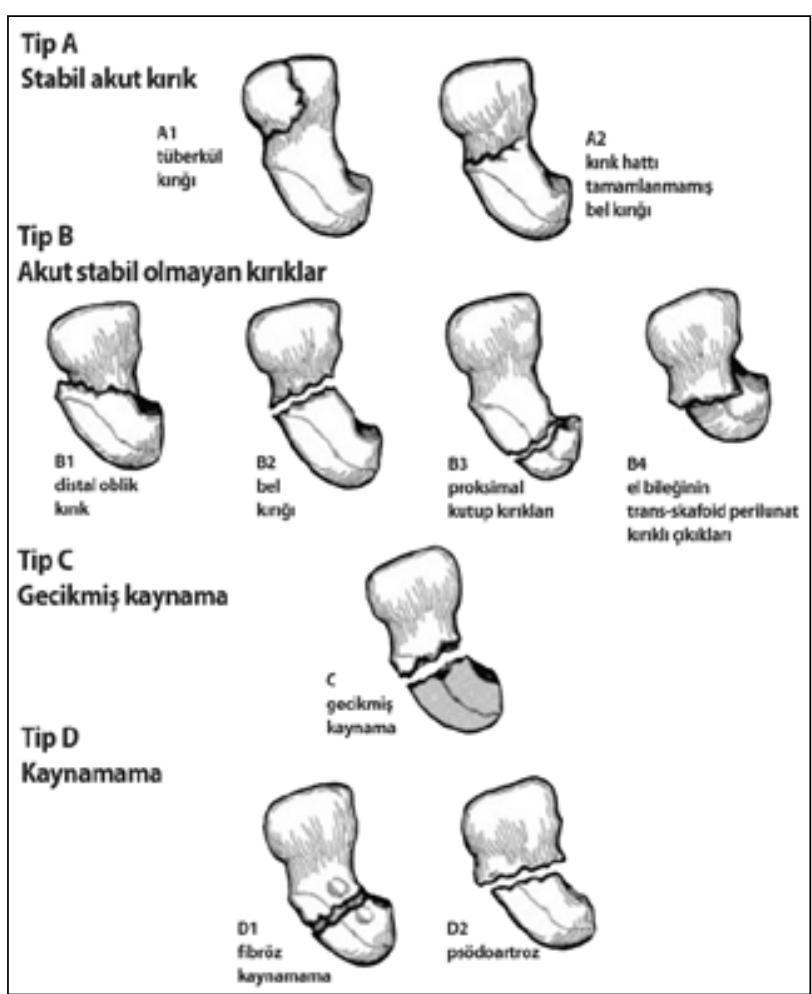

Şekil 3. Skafoid kırıklarının Herbert ve Fisher sınıflaması. ${ }^{[3]}$

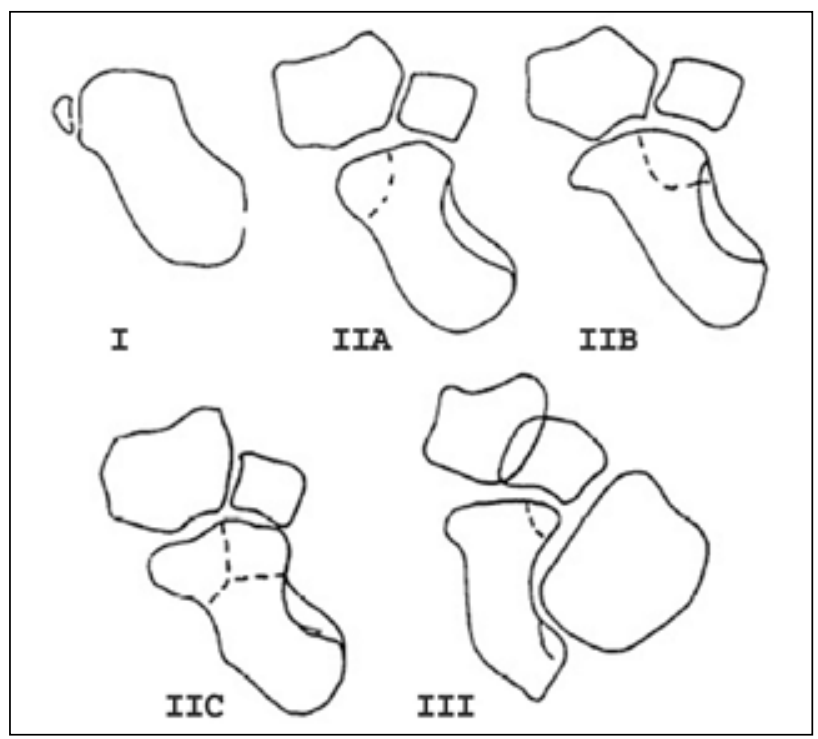

Şekil 4. Skafoid distal kutup kırıklarının Prosser sınıflaması.. ${ }^{[25]}$

Tablo 1. Skafoid kırıklarının Herbert ve Fisher sınıflaması

\begin{tabular}{|c|c|c|c|}
\hline Tip A (akut stabil kırıklar) & Tip B (akut stabil olmayan kırıklar) & Tip C (gecikmiş kaynama) & Tip D (kaynamama) \\
\hline A1: Tüberkül kırıkları & & D1: fibröz kaynamama \\
\hline A2: Bel bölgesinin & \multicolumn{2}{|l|}{$\begin{array}{c}\text { B2: bel bölgesinin yer değiştirmiş } \\
\text { veya hareketli kırıkları }\end{array}$} & D2: sklerotik kaynamama \\
\hline $\begin{array}{l}\text { yer değiştirmemiş } \\
\text { tam olmavan kırığı }\end{array}$ & \multicolumn{3}{|l|}{ B3: proksimal kutup kırıkları } \\
\hline & \multicolumn{3}{|l|}{ B4: el bileğinin kırıklı çıkıkları } \\
\hline & \multicolumn{3}{|l|}{ B5: parçalı kırıklar } \\
\hline
\end{tabular}


dorsal sulkus (oblik) ve Tip 3, proksimal kutup kırıkları olarak yeni bir sınıflama tanımlamıştır. ${ }^{[26]}$ Ancak, 1999 yılında Desai ve arkadaşları bu sınıflamaların hiçbirinin kırık kaynamasını tahmin etmek için prognostik olarak kullanılamayacağını göstermişlerdir. ${ }^{[27]}$

\section{TEDAVi}

Erken teşhis sonrası konservatif ve cerrahi tedavi ile \%90'ın üzerinde kaynama oranı elde edilmektedir. Akut olarak saptanıp tedavi edilen skafoid kırıklarının çoğunluğunda, yaklaşık üç ayda iyileşme meydana gelir. ${ }^{[28]}$ Proksimal kısım ve bel bölgesi skafoid kırıklarında deplasman ya da teşhis ve tedavide dört haftadan daha fazla gecikme ile, kaynama gecikmesi veya kaynamama önemli oranda artar. ${ }^{[29-31]}$ Tedavi edilmeyen skafoid kırıklarında kaynamama, hörgüç deformitesi ve avasküler nekroz meydana gelir. Skafoid kırıkları, skafoid kaynamamasına bağlı olarak ortaya çıkan karpal bölge çökmesini ve el bileği artritini önlemek için tedavi edilmektedir. ${ }^{[32]}$ Skafoidde kaynama, standart radyografiler ile üçüncü ayda güvenilir bir şekilde saptanamaz, yüksek çözünürlüklü BT ile değerlendirilir. ${ }^{[33,34]}$

\section{Proksimal kutup kırıkları}

Proksimal kutup kırıkları, kayma olup olmadığına bakılmaksızın stabil olmayan kırıklar sınıfına girer ${ }^{[35,36]}$ ve alçı tespiti ile tedavi süresi 12 hafta ya da daha uzun olabilir. Proksimal kutup kırıklarında başlangıçta dizilim düzgün olsa da, erken tanı ve uygun tedaviye rağmen konservatif tedavi ile kaynama oranı \%66'dır. ${ }^{[37]}$ Bu tip kırıklar cerrahi olarak tedavi edilmelidir. ${ }^{[35,36,38]}$ Perkütan vida uygulaması, yumuşak dokuya çok az hasar verir, kanlanmayı korur, proksimal kırıkların güvenle tamirine ve başsız kanüllü kompresyon vidasının merkezden gönderilmesine imkan sağlar. ${ }^{[31]}$

\section{Skafoid bel kırıkları}

Akut kayma olmayan skafoid bel kırıklarında kaynama için, kırı̆gı oluşturan parçaların hareketinin engellenmesi amacıyla el bileğinin hareketsiz hale getirilmesi gereklidir; bu da kırık stabilitesini arttırır. Akut kayma olmamış skafoid bel kırıklarında, stabilitenin deva$\mathrm{m}$ için uygulanan dirsek üstü başparmağı içine alan alçı, ${ }^{[39]}$ dirsek altı başparmağı içine alan alçı, ${ }^{[24]}$ el bileği nötral veya hafif ekstansiyonda tespit, ${ }^{[40]}$ el bilek ekstansiyon alçılı tespiti[33] ile kaynama oranı \%90-100 arasındadır. ${ }^{[24,28,29,33,39,40]}$ Alçı tespiti kaynama olana kadar devam ettirilir. Schramm, biyomekanik çalışma sonucunda, kayma olmayan skafoid bel kırıklarında kırık hattında hareketi sınırlamak için hareketsizliğin gerekli, başparmak tespitinin ise gereksiz olduğunu bildirmiştir. ${ }^{[41]}$ Koneshiro, kadavra çalışmasında kısa kol alçı ile kırık parçaları arasında 1-4 mm translasyon olduğunu bildirerek, uzun kol alçı önermiştir. ${ }^{[42]}$ Alçı tespiti, kayma olmayan kırıklar için 6-8 hafta uygulanır ve kaynama BT ile değerlendirilir. BT'de kaynama yok ise alçı tespitine 4-6 hafta daha devam edilir. Direkt grafi veya BT ile takiplerde kaynama olmayan olgulara, kırık hattında ortaya çıkacak aralık veya açılanmada ya da 12 hafta sonunda kaynamayan kırıklara, perkütan vida tespiti veya açık cerrahi tedavi ve gerekirse kemik aşısı ile birlikte cerrahi tedavi uygulanması önerilmektedir. ${ }^{[33]}$

Dias, tespit süresini kısa tutarak erken hareket başlamak için "agresif-konservatif" tedavi uygulamıştır; kayma olmayan skafoid bel kırıklı 44 olguda, dirsek altı başparmağı serbest bırakan, el bileğinin hafif ekstansiyonda olduğu 6-8 haftalık alçı tespiti ile erken Herbert vida tespitini, randomize, ileriye dönük kontrollü çalışmada karşılaştırmıştır. İşe dönüş, erken Herbert vida tespitinde beş hafta iken kısa kol alçı tespitinde 6-8 hafta arasındadır. Erken Herbert vida tespitinin kavrama kuvveti ve el bileği hareketleri açısından geçici bir üstünlüğünün olduğunu fakat işe dönüş ve aktiviteler açısından konservatif tedaviye açık bir fark göstermediğini bildirmiştir. On iki hafta takip sonunda agresifkonservatif tedavi grubunda kaynama elde edilmeyen 10 olgunun 7'sine greftle birlikte Herbert vida tespiti uygulamıştır. Dias'a göre, vida sadece bir internal splint'tir. ${ }^{[33]}$

Akut skafoid kırık olgularının \%25'inde, başlangıç radyografisinde kırık hattı görülmez. Proksimal kısım ve bel bölgesi skafoid kırıklarının teşhis ve tedavisinde dört haftadan daha fazla gecikme ile kaynama gecikmesi veya kaynamama önemli oranda artar. ${ }^{[29,30]} \mathrm{EI}$ bileği aşırı ekstansiyonda düşme sonrası enfiye çukur hassasiyeti ile gelen ve radyografide kırık hattı görülmeyen skafoid kırık şüpheli olgularda, dirsek altı kısa kol başparmak alçısı yapılır. Alçı 10-14 gün sonra çıkarılarak el bileği muayene edilir ve kontrol radyografisi alınır. Radyografide kırık hattında kemik rezorpsiyonuna bakılır ve kayma yok ise kısa kol başparmak alçısı veya perkütan başsız kompresyon vida tespiti uygulanır. Radyografide kırık hattı görülmüyor ve enfiye çukur hassasiyeti devam ediyor ise, MR ile skafoid değerlendirilir. MR'de kırık görülüyor ise, kısa kol başparmak alçısı veya perkütan başsız kompresyon vida tespiti ile tedaviye devam edilir. ${ }^{[1,4,14]}$

\section{Cerrahi tedavi}

İş, günlük aktivite veya atletik faaliyetlere erken dönülmesi, düşük morbidite, kaynama oranlarının yüksekliği, hasta memnuniyeti, tespit süresinin kısa olması ve tespit materyallerindeki iyileşmeler internal tespite olan eğilimi arttırmaktadır. ${ }^{[28,33,43,44]}$ Alçı ile tespit, kırık parçaları arasındaki hareketi tam olarak 
önleyemez. ${ }^{[15]}$ Skafoid kırıklarının internal tespiti, kaynama olana kadar güvenli erken harekete izin verir. Skafoidin, aksı boyunca santral yerleştirilen vida ile sabit tespiti skafoid üzerine gelen yükleri nötralize eder, kırık parçaları arasında sıkışmayı sağlar. ${ }^{[45]}$ Perkütan vida tespiti ile iyileşme alçı tespiti ile olduğundan daha kısadır ( 12 yerine 7 hafta kaynama süresi ve 15 yerine 8 hafta işe dönüş süresi). ${ }^{[46]}$

Cooney, skafoid kırık hattında 1 mm'den az kayma, normal interkarpal dizilim (kapitolunat açı $0-15^{\circ}$, skafolunat açı $30-60^{\circ}$ ) ve distal kutup kırığını akut stabil kırık olarak tanımlamıştır. 1 mm'den fazla kayma, yan grafide skafoid parçaları arası açının $35^{\circ}$ 'den büyük olması, önemli kemik kaybı veya parçalanma, perilunat kırık, DISı dizilimi (kapilunat açının $15^{\circ}$ 'den, skafolunat açının $60^{\circ}$ 'den fazla olması) ve eşlik eden proksimal kutup kırığını ise stabil olmayan kırık olarak kabul etmiştir. ${ }^{[24]}$

Skafoid kırıklarında cerrahi tedavi endikasyonları: ${ }^{[24,33,45]}$

- Kırık hattında 1 mm'den fazla yer değiştirme (kaynamama oranı yaklaşık \%50).

- Proksimal kutup (yer değiştirmiş veya değiştirmemiş kırık).

- Büyük kemer yaralanması (trans-skafoid perilunat yaralanma).

- Parçalı kırık.

- Meslek (cerrah, elit sporcu).

- Alçilı tespite uyumsuz hasta.

Skafoid kırıklarında azami kompresyon sağlanması için kanüllü başsız kompresyon vida tespitinin, kayma olmayan skafoid proksimal kutup kırıklarında dorsal, distal kutup kırıklarında volar uygulanması önerilmektedir. Bel bölgesi kırıklarında dorsal ya da volar yaklaşımla vida uygulanabilir. Kanüllü başsız kompresyon vidasının santral yerleştirilmesi azami kompresyon sağlar, kırık hattında tespitin sağlamlığını ve kaynama oranını arttırır. $^{[31,47]}$ Başsız kompresyon vidası, uygulamada ölçümden $4 \mathrm{~mm}$ daha kısa seçilir ve skafoid eklem yüzünün $2 \mathrm{~mm}$ altında kalacak şekilde yerleştirilir. ${ }^{[0,48]}$ Vidanın merkezi yerleştirilmesi ile \%43 daha fazla sağlamlık elde edilmiş, deneysel olarak kırık hattında $2 \mathrm{~mm}$ kayma oluşturabilmek için eksentrik vida yerleştirilmesine göre \%113 daha fazla güce ihtiyaç duyulmuş (59,1 Newton'a karşılık 126 Newton) ve tespitin tamamen yitirilmesi için ise \%39 daha fazla yük (513 Newton'a karşılık 712 Newton) bindirilmesi gerektiği gösterilmiştir. ${ }^{[49]}$

\section{Kırığın cerrahi tedavisinde Herbert ${ }^{\odot}$ ve Acutrak $^{\odot}$ vidalar}

Herbert ve Fisher'in skafoid kırıklarının tespiti için 1984 yılında geliştirdiği kompresyon vidasının proksimal ve distali yivlidir, ara kısımda ise yiv yoktur; başsızdır ve titanium alaşımdan imal edilmiştir. ${ }^{[3]}$ Proksimaldeki yivlerin aralığı daha dardır. Vidayı sıkarken, distal parçasının proksimale göre daha çok yol kat etmesi sayesinde kompresyon sağlanır. Vida tamamen kemiğin içine gömülür. Acutrak ${ }^{\odot}$ vidanın (Acumed, Beaverton, Oregon) ise tamamı yivlidir, başsızdır, kanüllüdür ve yiv aralıkları ucundan başına doğru azalır; Herbert ${ }^{\odot}$ vidası ile aynı mantıkla kompresyon yapar, ancak kompresif güç tüm vida boyunca yayılır. Kullanılan vidadan bağımsız olarak, skafoid kemiğin içerisinde santral yerleşimli olmasının kaynama süresini kısalttı̆̆ı ve kanüllü vidaların santral yerleşim oranının kanülsüz vidalara göre daha yüksek olduğu gösterilmiştir. ${ }^{[50,51]}$ Herbert vidasının bu eksikliği Herbert-Whipple ${ }^{\odot}$ vidasının (Zimmer, Warsaw, IN) geliştirilmesiyle giderilmiştir. Acutrak ${ }^{\odot}$ vidanın Herbert $^{\odot}$ vidasından daha fazla kompresyon yaptığı ve parçaların temasını bozmak için gerekli torkun Acutrak ${ }^{\odot}$ vidalarda daha yüksek olduğu gösterilmiştir. ${ }^{[52]}$

\section{Skafoid kırıklarında perkütan vida tespiti}

Skafoid kırıklarının perkütan internal tespiti, açık redüksiyon - internal tespit veya alçı ile tedaviye göre daha az morbidite ve daha fazla kaynama ile birliktedir. Teknik, akut proksimal kutup kırıkları, kayma olmuş ya da olmamış akut bel kırıkları ve kollaps veya avasküler nekrozla birlikte olmayan kaynama gecikmelerinde uygulanır. ${ }^{[31]}$ Kayma olmuş ya da olmamış skafoid kırıklarında tam kaynama bildirilmektedir. ${ }^{[31,44,46]}$ Seçilmiş skafoid kaynamamalarında (dizilimi iyi olan ve sklerozu veya kaynamama sahasında kemik rezorpsiyonu aşırı olmayan) perkütanöz tespit ile kemik grefti alınan donör saha morbiditesi de engellenmiş olur. ${ }^{[31]}$ Kırık redüksiyon ve dizilimi floroskopi ve/veya artroskopi yardımı ile değerlendirilir. ${ }^{[31,43-45]}$ Ameliyat genel veya bölgesel anestezi altında uygulanır.

\section{Kontrendikasyonlar}

Perkütan teknik için redükte edilemeyen kırıklar, hörgüç deformitesi, açık veya parçalı kırıklar, skafoid kırığına eşlik eden karpal kırıklı çıkıklar, ciddi sklerozla birlikte olan kaynamamalar ve psödoartrozlar kontrendikasyonları oluşturur. ${ }^{[53]}$

\section{Dorsal perkütan tespit}

Skafoid kırık tespitinde dorsal perkütan yaklaşım kayma olmayan kırıklar ya da kayma olmuş kırıklarda, kılavuz telleri kullanılarak perkütanöz manipülasyon ile kırık redükte edilebiliyorsa uygulanabilir. Proksimalden distale doğru dorsal yaklaşım ile kılavuz tel gönderilmesi, skafoidin merkezi aksının tam olarak hedeflenebilmesi ve vidanın skafoid içerisinde doğru yerleştirilebilmesine 
olanak sağlar; iyileşme zamanı kısalır ve vida yivlerinin dışarıda kalma riski azalır; volar karpal bağlar ve skafoid kan akımının yaralanmasından kaçınılır. Dorsal yaklaşımda, skafotrapezial eklem merkez noktası ya da başparmağın tabanı hedef alınır. Ayrıca vidanın proksimalden distale doğru gönderilmesi ile proksimal skafoid kırıklarının daha rijid tespiti mümkün olur. Dorsal perkütan tespitte el bileğinin aşıı fleksiyona alınması, hörgüç deformitesine yol açarak, stabil olmayan skafoid kırığında kaymaya neden olabilir. ${ }^{[31]}$

\section{Cerrahi teknik ${ }^{[53]}$}

Skafoidin yüzük görüntüsünü elde etmek için el bileği fleksiyon, pronasyon ve ulnar deviyasyona getirilebilir, ancak görüntü elde etmek ve bu pozisyonda çalışmak çoğunlukla güçtür. Alternatif olarak, kılavuz teli elde tutarken, el bileğini proksimal kutup açığa çıkacak, ancak hala iyi bir PA görüntüye izin verecek kadar fleksiyona almak daha kolay olabilir. Başlangıç noktasının skafoidin proksimal ulnar yüzünde olduğu doğrulanır. Arka-ön ve yan görüntüler ile gidiş yolu kontrol edilerek kılavuz tel ilerletilir (Şekil 5 b, c). Tel yerleştirilip volarden çıkartılır ve radyokarpal eklem serbest kalınca el bileği ekstansiyona alınarak arka-ön grafide uygun tel yerleşimi doğrulanır. Santral olarak yerleştirilen kılavuz tel üzerinden vida uzunluğu ölçülür. Daha sonra el bileği tekrar fleksiyona alınıp kılavuz tel retrograd olarak dorsale ilerletilir. Telin çıkacağı yere küçük insizyon yapılır. Tel skafoid kemikten retrograd olarak gelirken, ekstansör tendonları yakalamaması için yumuşak dokular bir hemostat ile ayırılır. Genellikle tel üçüncü ve dördüncü ekstansör kompartman aralığından geçer. Kılavuz tel üzerinden kanüllü dril ile oyma işlemi yapılır. Ölçülenden 4 mm kısa seçilen kanüllü başsız vida kılavuz tel üzerinden yerleştirilir (Şekil $5 \mathrm{~d}-\mathrm{g}$ ).

\section{Volar perkütan tespit}

Haddad, 15 skafoid kırığında volar perkütan tespitle iki ayda tam kaynama elde etmiş ve hastalar beş haftada işlerine başlamıştı. ${ }^{\left[{ }^{[3]}\right]}$ Volar perkütan vida tespiti için, kayma olmayan kırıklar veya çok az kayma olan $(<1 \mathrm{~mm})$ transvers skafoid bel kırıkları idealdir (Herbert, Tip A2); kapalı anatomik redükte edilebilen, kayma oluşmuş skafoid bel kırıklarında da (Herbert, Tip B2) uygulanabilir. ${ }^{[3]}$ Perkütan teknik ile yumuşak doku disseksiyonu daha azdır ve volar karpal bağların bütünlügü korunur.. ${ }^{[1]}$ Palmar perkütan yaklaşımda, skafolunat bağın skafoide yapışma yerinin proksimal ulnar köşesi hedef alınır.

\section{Cerrahi teknik}

Hasta supin pozisyonda yatar ve kol abduksiyonda radyolusen masa veya floroskopi üzerine alınır.
[46] El bileği ekstansiyonu için el bileği altına yuvarlak havlu konur. Cerrahi işlem, traksiyon uygulamadan başparmak parmak askısına alınarak da yapılabilir. ${ }^{[1]}$ Çok az kayma olan kırıklarda nazik traksiyon altında el bileğine ekstansiyon ve radyal veya ulnar deviyasyon ile kapalı redüksiyon yapılır. Floroskopi altında skafotrapeziotrapezoid eklem volarden belirlenir ve $1 \mathrm{~cm}$ transvers insizyon yapilır. Künt disseksiyon ile skafoid tüberkülüne ulaşılır. Kılavuz tel $(1,1 \mathrm{~mm})$ skafoid volar distal tüberkülünden girer ve proksimale yönlenerek dorsal ve ulnar yönde proksimal kutup merkezine floroskopi kontrolünde gönderilir. Kılavuz tel üzerinden vida boyu ölçülür. Rotasyonu engellemek için merkezi tele paralel ikinci bir tel gönderilir (Şekil 6 b). Drillemeden sonra, ölçülenden $4 \mathrm{~mm}$ kısa başsız kompresyon vidası floroskopi altında uygulanır. Vida eklem içinde çıkıntı olarak kalmasın diye gömülür (Şekil 6 c). Teller çekilir, insizyon kapatılır ve kısa kol alçı atel uygulanır (Şekil $6 \mathrm{~d}-\mathrm{h}$ ). ${ }^{[43,46]}$

\section{Skafoid kırıklarında açık cerrahi redüksiyon ve tespit}

Skafoid kırıklarında açık redüksiyon ve internal tespit kapalı yöntemlerle redükte edilemeyen akut kaymış kırıklar, hörgüç deformitesi, parçalı açık kırıklar, kaynama gecikmeleri ve kaynamamalarda uygulanır. Açık redüksiyon ve internal tespitte radyokarpal bağ, skafotrapezial eklem ve skafoidi besleyen damarların da yaralanma riski vardır. ${ }^{[33,36]}$

\section{Dorsal açık yaklaşım}

Açık dorsal yaklaşım ile skafoide kolay ulaşılır. Direkt redüksiyon ile başsız kompresyon vidası uygulanır. Skafoid proksimal kutup ve bel kırıkları cerrahi tedavisinde kullanılır. ${ }^{[36,45]}$ Ancak bu yaklaşım skafoidin vaskülaritesine hasar verebilir. Avantajı, skafoidin santral aksının daha iyi hedeflenebilmesi ve vidanın skafoidin içine daha kusursuz yerleşimine izin vermesidir. Bununla birlikte volar karpal bağların hasarı önlenmiş olur ve stabilite korunur. Kaynama gecikmesi ve çökme olmayan kaynamamış kırıklarda da kemik aşısı ile birlikte uygulanır. ${ }^{[36]}$

\section{Cerrahi teknik ${ }^{[32]}$}

Volarde skafoid tüberkülü, dorsalde lister tüberkülü ve radius stiloidinin tipi işaretlenir. Radyokarpal eklem ve skafolunat aralık üzerinde $1 \mathrm{~cm}$ longitudinal insizyon yapılır. Ekstansör pollisis longus tendonu gevşetilir ve radyale alınır. Dördüncü ekstansör kompartman açılır ve ekstansör tendonlar ulnar tarafa alınır. Skafolunat eklem seviyesinde dorsal radyokarpal eklem kapsülü açılır. Bu yaklaşımla skafoidin proksimal 


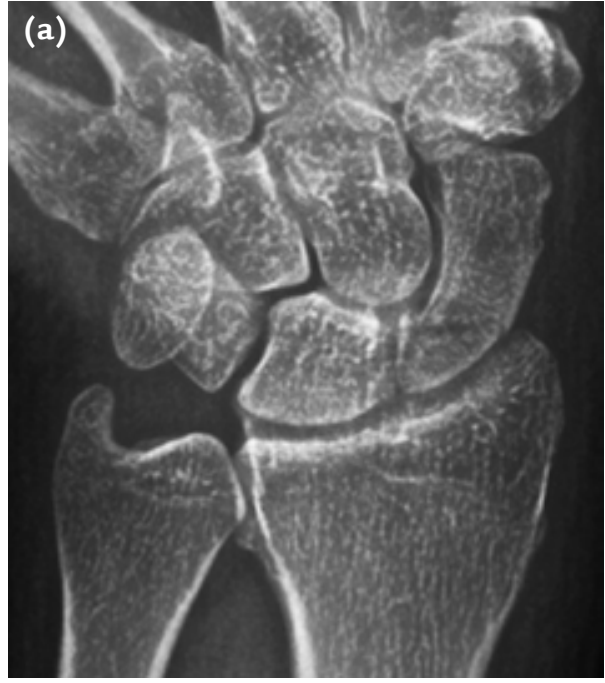

(d)

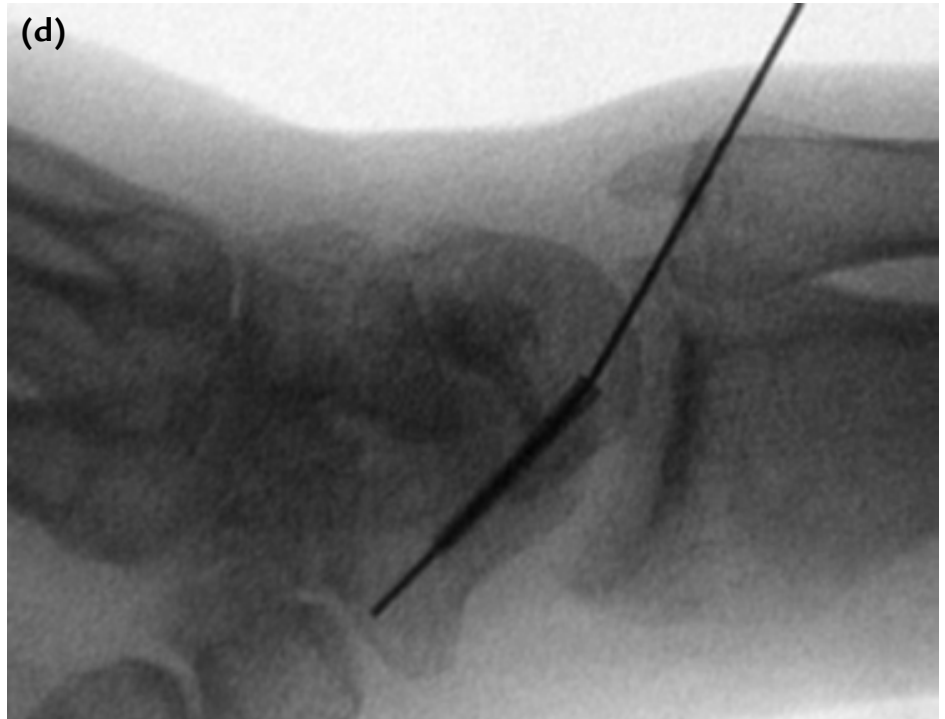

(b)

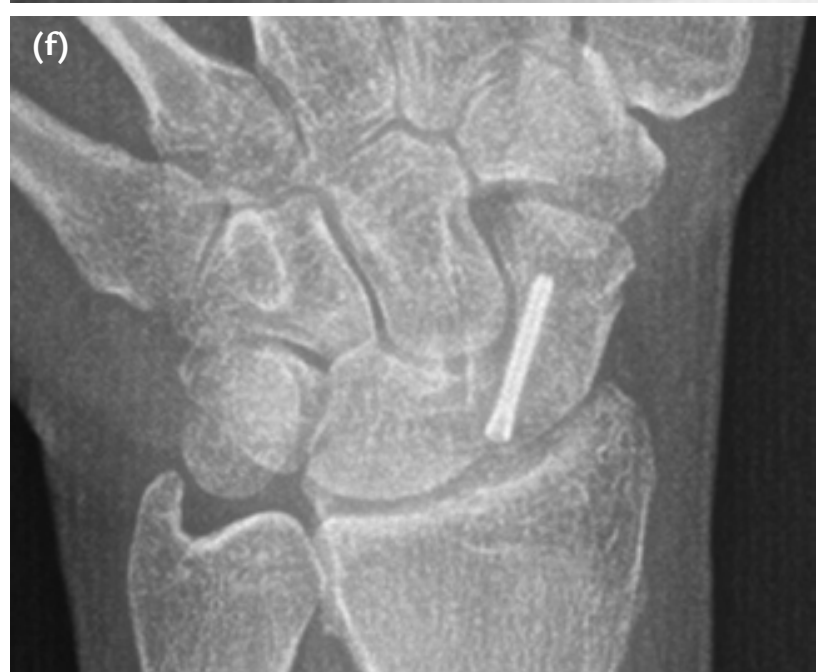

\section{(g)}

(e)
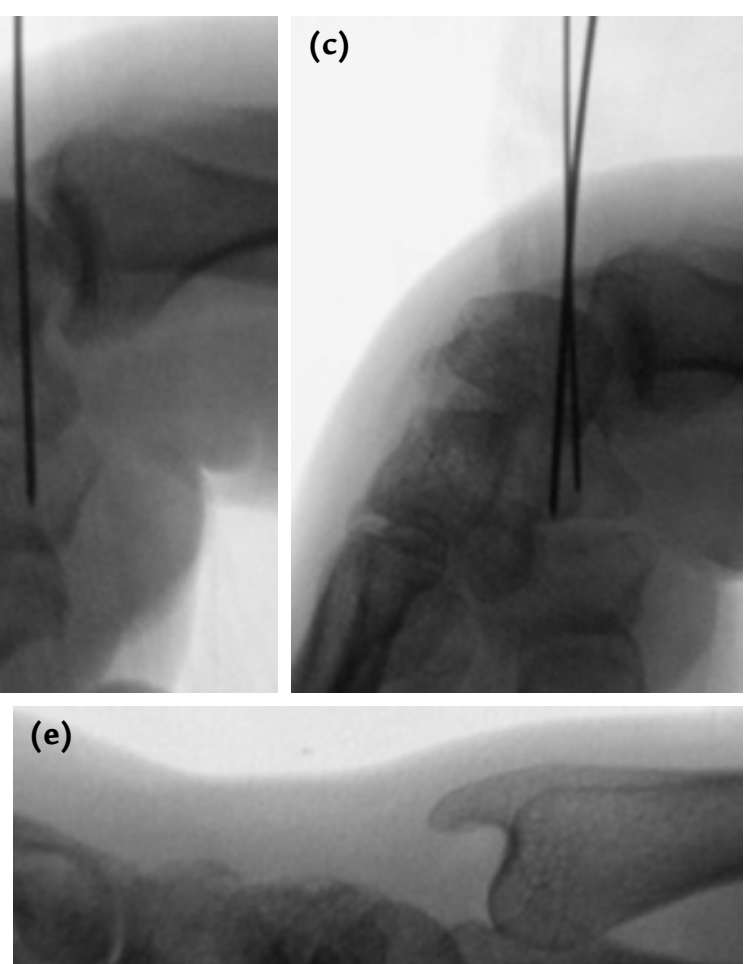

Şekil 5. a-g. Kayma olmuş skafoid proksimal kutup kırı̆ına redüksiyon ve dorsal perkütan bașsız kompresyon vidası uygulanan olgunun cerrahi uygulama ve radyolojik görüntüleri. Arka-ön radyografi (a), dorsalden perkütan uygulanmış başsız kompresyon vida kılavuz teli ve rotasyonu engellemek için gönderilen kılavuz telin floroskopi görüntüsü $(b, c)$, pronasyonda oblik floroskopide kılavuz tel üzerinden vida uygulaması (d, e) ve skafoidin kaynama olan takip radyografileri (f, $g$ ). 

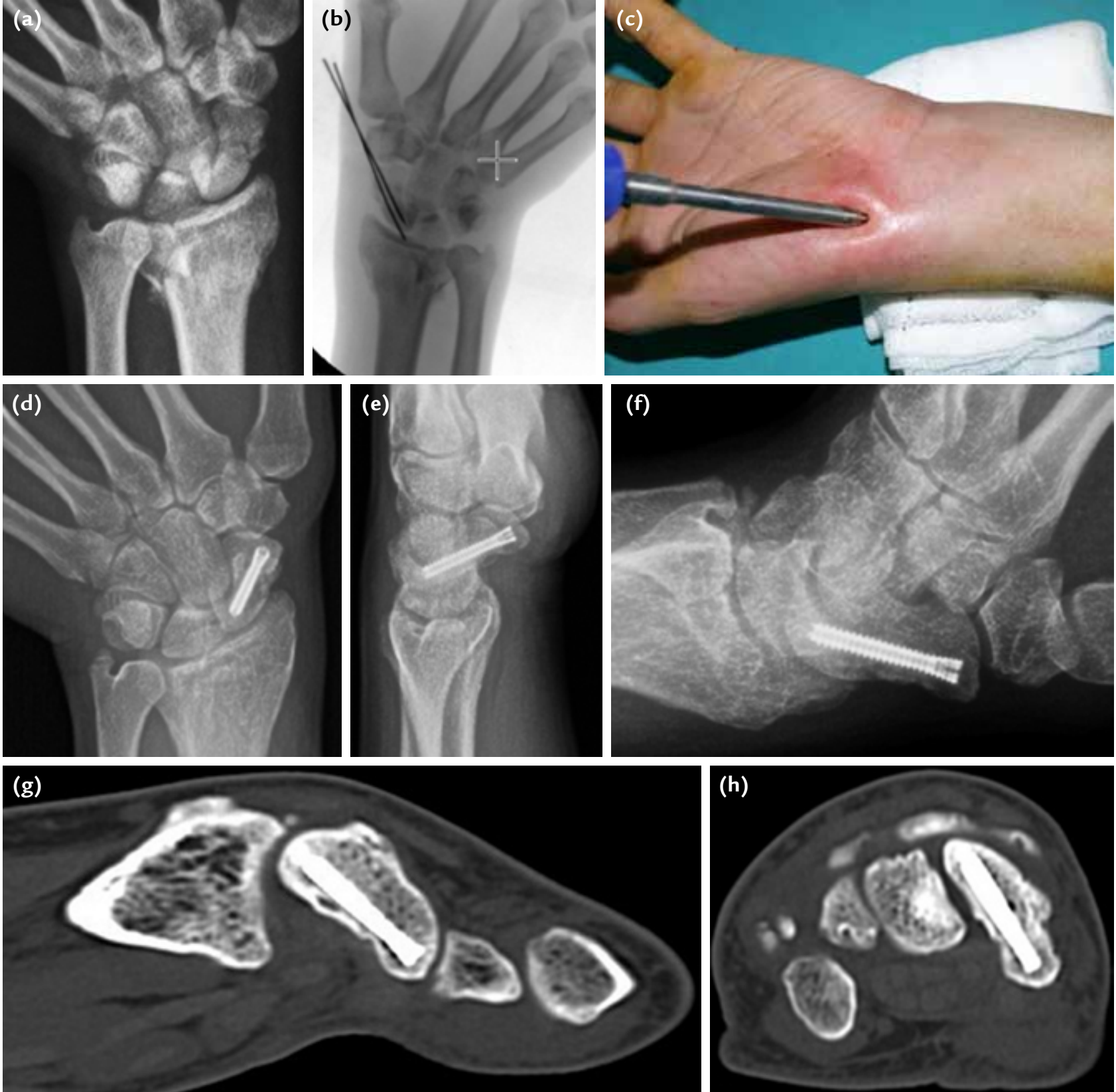

Şekil 6. a-h. Yüksekten düşme sonrası oluşan skafoid kırığına palmar perkütan başsız kompresyon vidası ve distal radius parçalı kırığına da açık cerrahi tedavi uygulanan olgunun radyolojik ve klinik görüntüleri. Arka-ön radyografi (a), floroskopide volarden perkütan uygulanmış başsız kompresyon vida kılavuz teli ve rotasyonu engelleyen tel (b), başsız kompresyon vida uygulaması (c), skafoid ve radius alt ucun arka ön, el bileği ulnar deviyasyonda skafoid ve pronasyonda oblik radyografilerde kaynamış görüntüleri (d-f) ve skafoid aksına uygun olarak çekilmiş koronal ve sagittal BT görüntülerinde kırık kaynaması (g, h).

2/3'ünün tamamı, radyal stiloid ve distal radiusun skafoid fossası görülebilir hale gelir. El bileği sarılarak yuvarlanmış üç adet havlu ile yapılan yastık üzerinden fleksiyona alınır. Kılavuz tel skafoid içine santral yerleşim için skafolunat bağ proksimal membranöz parçası yapışma noktasının $3 \mathrm{~mm}$ radyaline yerleştirilir. Bu noktaya bir doku koruyucu veya 14 numara intravenöz kanül konur ve skafoid tüberkülünün $5 \mathrm{~mm}$ distalindeki bir noktaya yönlendirilir. Perkütan teknik gibi devam edilir ve işlem bittiğinde kapsülotomi açık bırakılır ve cilt kapatılır. El bileği kısa kol atel ile istirahate alınır ve parmak egzersizlerine başlanır. 


\section{Volar açık yaklaşım}

Volar açık yaklaşım skafoid distal kırıkları veya bel kırıkları ve kaynamamalarında kullanılır. Bu yaklaşımla dorsal kan akımı hasardan korunur ve skafoidin volar yüzeyi daha iyi değerlendirilir. Hörgüç deformitesini düzeltmek ve karpal yüksekliği restore etmek için yapısal kortikokansellöz kemik aşısı kullanılır. ${ }^{[54]}$ Parçalı kırıklarda kemik parçaları çıkarılmalı ve skafoidin uzunluğunu sağlamak için oluşan boşluk yeteri kadar kemik grefti ile doldurulmalıdır. ${ }^{[35]}$

\section{Cerrahi teknik}

Fleksör karpi radyalis (FKR) tendonu üzerinden longitudinal bir insizyon yapılır. İnsizyon skafoid tüberkülüne doğru oblik olarak distale uzatılır. FKR ulnar tarafa çekilir ve FKR'nin kılıfının tabanından, radyal arterin ulnar tarafindan diseksiyona devam edilir ve el bilek eklem kapsülü ortaya konur. Uzun radyolunat ve radyoskafokapitat bağ arasından keskin insizyon ile girilir. Kırık hattı açığa çıkarılır. Kırık redüksiyonu, deformite düzeltilmesi ve gerekirse kemik aşılaması yapılır. ${ }^{[1,54]}$ Kılavuz telinin yerleşmesini kolaylaştırmak için skafo-trapezium eklem kapsülü açılır ve trapeziumun volar parçası alınabilir. Ön kola sagittal ve koronal planda $45^{\circ}$ açı ile önce merkezi kılavuz teli ve ona paralel ikinci bir kılavuz tel skafoidde distalden proksimale doğru yerleştirilir. Skopi kontrolü altında santral olan tel seçilir. Boy ölçümü yapılır ve $4 \mathrm{~mm}$ kısa olan başsız kompresyon vidası hazırlanır. Kılavuz tel üzerinden vida yolu hazırlanır ve vida ile tespit yapılır. ${ }^{[54]}$ Kapatılma işleminde, iyatrojenik karpal instabilite ile ilgili problemlerden kaçınmak için volar karpal bağlar dikkatli bir şekilde karşılaştırılarak tamir edilmelidir. EI bileği kısa kol atel ile istirahate alınır ve parmak egzersizlerine başlanır (Şekil 7). ${ }^{[1,54]}$
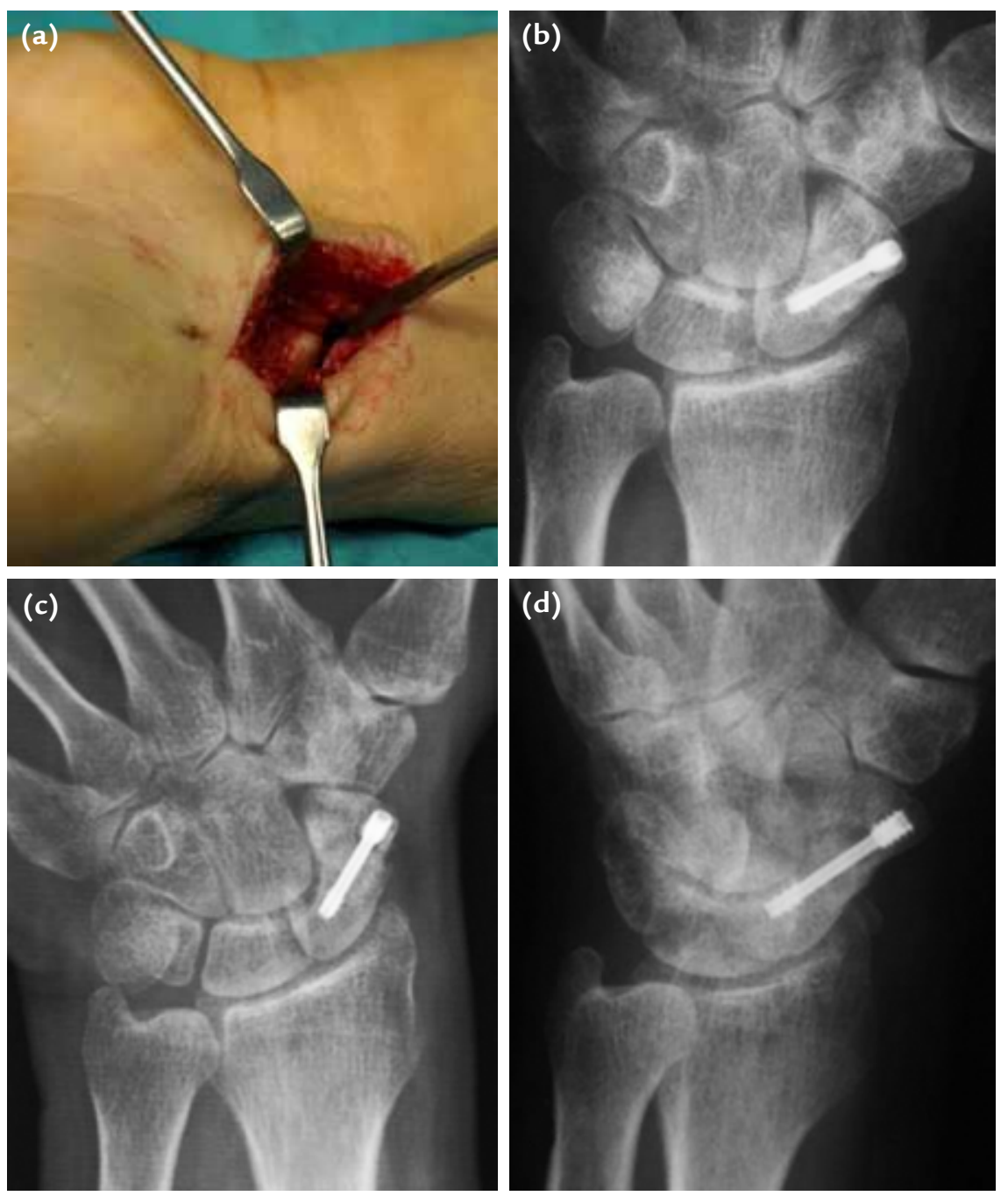

Şekil 7. a-d. Şekil 1'de radyografileri görülen olgunun; volar açık redüksiyon ile hörgüç deformitesi düzeltilmesi ve kemik aşısı uygulaması (a) ve arka-ön, skafoid ve pronasyonda oblik radyografide skafoidin kaynama radyolojik görüntüleri (b-d). 


\section{Artroskopik yardımlı redüksiyon ve perkütan vida tespiti}

Artroskopik redüksiyon ve perkütan vida tespiti, tek işlemle kırığın kabul edilebilir restorasyonu yanı sıra, eklem içi diğer yaralanmaların da değerlendirilmesi ve tedavisine imkan tanır. Artroskopik değerlendirme esnasında kaymamış kırıkların kaymasını önlemek için önemli bir püf noktası, skafoide önceden santral bir tel yerleştirmektir. ${ }^{[55]}$ Başsız kompresyon vidası, dorsal perkütan yolla floroskopi ve artroskopi kontrolünde kırık redüksiyonu ve vida pozisyonu kontrol edilerek gönderilir. Skafoidin, akut proksimal kutup kırıkları, akut bel bölgesi kırıkları, kollaps veya avasküler nekrozun eşlik etmediği kaynama gecikmesi olgularında uygulanır. On yedi skafoid bel bölgesi ve 10 proksimal kutup kırığında artroskopi yardımlı dorsal perkütan tespitle 12 haftada tam kaynama elde edilmiştir. Yaralanmadan sonraki bir ay içinde 18 ve yaralanması bir ayı geçen 9 olguda tam kaynama sağlanmıştır. ${ }^{[31]}$

\section{Cerrahi teknik ${ }^{[53]}$}

Kayma olan kırıklar için, skopi kontrolü altında distal kutbun santral aksı boyunca 1,1 mm kılavuz teli yerleştirilir (dorsal ya da volardan giriş) ve 1,6 mm kılavuz teli redüksiyonda kılavuz olarak kullanmak için her bir parçaya yerleştirilir. Traksiyon uygulanırken artroskopi ile radyokarpal ve midkarpal eklem incelenir. Kılavuz tellerle proksimal parça fleksiyona ve distal parça ekstansiyona getirilerek kırık redüksiyonu sağlanır. Perkütan yerleştirilen hemostat ile redüksiyona yardım edilebilir. Floroskopi ve artroskopi ile redüksiyon kontrol edilir. Daha önceden distal parçaya santral aksta yerleştirilen tel, retrograd olarak redüksiyonu stabilize etmesi için ilerletilir. Bazen, redüksiyon sağlandığında, önceden yerleştirilmiş olan orijinal kılavuz tel santral akstan geçmeyebilir. Bu tel redüksiyonu korumak ve rotasyonu önlemek için yerinde bırakılır ve ikinci bir kılavuz teli santral aksta gönderilir. Teller arasında, bir oyucu veya vidanın santral akstaki tel üzerinden ilerleyebileceği kadar mesafe bırakılması önemlidir. Kılavuz tel üzerinden vida yolu hazırlanır ve $4 \mathrm{~mm}$ kısa seçilen başsız kompresyon vidası ile tespit yapılır.

\section{Distal kutup kırıkları}

Zengin kan akımı olan skafoid distal kutup kırıklarında, 4-8 hafta alçı tespiti ile kaynama oranı yüksektir. ${ }^{[25]}$ El bileği $45^{\circ}$ pronasyonda oblik çekilmiş radyografiler tüberkül kırıklarını daha iyi gösterir. Kaynamama ve yanlış pozisyonda kaynama nadirdir. Kayma olmuş ve impakte kırıklarda dejeneratif artrit riskini azaltmak için cerrahi tedavi uygulanabilir. ${ }^{[25,26]}$

\section{Komplikasyonlar}

Cerrahi tedaviye bağlı en sık görülen komplikasyon vidanın çok uzun olması ya da merkeze yerleştirilememesidir. ${ }^{[53]}$ Diğer komplikasyonlar; enfeksiyon, kompleks bölgesel ağrı sendromu, vidanın dışarıda olması, cerrahi uygulama zorluğu, skar problemleri, yumuşak doku yaralanması (cilt sinirleri, tendonlar, radyal arter), skafotrapeziotrapezoid eklem osteoartritidir. ${ }^{[28,33,40]}$ Cerrahi olmayan grupta ise komplikasyon radyokarpal osteoartrittir. ${ }^{[1]}$

\section{KAYNAKLAR}

1. Sendher R, Ladd AL. The scaphoid. Orthop Clin North Am 2013;44(1):107-20. CrossRef

2. Russe O. Fracture of the carpal navicular. Diagnosis, nonoperative treatment and operative treatment. J Bone Joint Surg Am 1960;42-A:759-68.

3. Herbert TJ, Fisher WE. Management of the fractured scaphoid using a new bone screw. J Bone Joint Surg $\mathrm{Br}$ 1984;66(1):114-23.

4. Adams JE, Steinmann SP. Acute scaphoid fractures. Orthop Clin North Am 2007;38(2):229-35.

5. Wolf JM, Dawson L, Mountcastle SB, Owens BD. The incidence of scaphoid fracture in a military population. Injury 2009;40(12):1316-9. CrossRef

6. Van Tassel DC, Owens BD, WolfJM. Incidence estimates and demographics of scaphoid fracture in the U.S. population. J Hand Surg Am 2010;35(8):1242-5. CrossRef

7. Ring D, Jupiter JB, Herndon JH. Acute fractures of the scaphoid. J Am Acad Orthop Surg 2000;8(4):225-31.

8. Cooney WP, Dobyns JH, Linscheid RL. Fractures of the scaphoid: a rational approach to management. Clin Orthop Relat Res 1980;(149):90-7.

9. Freedman DM, Botte MJ, Gelberman RH. Vascularity of the carpus. Clin Orthop Relat Res 2001;(383):47-59.

10. Gelberman RH, Menon J. The vascularity of the scaphoid bone. J Hand Surg Am 1980;5(5):508-13.

11. Ruby LK, Stinson J, Belsky MR. The natural history of scaphoid non-union. A review of fifty-five cases. J Bone Joint Surg Am 1985;67(3):428-32.

12. Parvizi J, Wayman J, Kelly P, Moran CG. Combining the clinical signs improves diagnosis of scaphoid fractures. A prospective study with follow-up. J Hand Surg Br 1998;23(3):324-7.

13. Grover R. Clinical assessment of scaphoid injuries and the detection of fractures. J Hand Surg Br 1996;21(3):341-3.

14. Murthy NS. The role of magnetic resonance imaging in scaphoid fractures. J Hand Surg Am 2013;38(10):2047-54. CrossRef

15. Ring D, Lozano-Calderón S. Imaging for suspected scaphoid fracture. J Hand Surg Am 2008;33(6):954-7. CrossRef

16. Mallee W, Doornberg JN, Ring D, van Dijk CN, Maas M, Goslings JC. Comparison of CT and MRI for diagnosis of suspected scaphoid fractures. J Bone Joint Surg Am 2011;93(1):20-8. CrossRef

17. Grewal R, Suh N, Macdermid JC. Use of computed tomography to predict union and time to union in acute scaphoid fractures treated nonoperatively. J Hand Surg Am 2013;38(5):872-7. CrossRef 
18. Kapandji IA. The Wrist. In: Maloine SA, editor. The Physiology of the Joints. 5th ed. Churchill Livingstone; 2006. p.130-64.

19. Wolfe SW, Neu C, Crisco JJ. In vivo scaphoid, lunate, and capitate kinematics in flexion and in extension. J Hand Surg Am 2000;25(5):860-9.

20. Rainbow MJ, Kamal RN, Leventhal E, Akelman E, Moore DC, Wolfe SW, Crisco JJ. In vivo kinematics of the scaphoid, lunate, capitate, and third metacarpal in extreme wrist flexion and extension. J Hand Surg Am 2013;38(2):278-88. CrossRef

21. Weber ER, Chao EY. An experimental approach to the mechanism of scaphoid waist fractures. J Hand Surg Am 1978;3(2):142-8.

22. Horii E, Nakamura R, Watanabe K, Tsunoda K. Scaphoid fracture as a "puncher's fracture". J Orthop Trauma 1994;8(2):107-10.

23. Gaebler C. Fractures and dislocations of the carpus. In: Bucholz RW, Heckman JD, Court-Brown CM, editors. Rockwood and Green's fractures in adults. 6th ed. Philadelphia, Pa: Lippincott Williams \& Wilkins; 2006. p.857-908.

24. Cooney WP 3rd. Scaphoid fractures: current treatments and techniques. Instr Course Lect 2003;52:197-208.

25. Prosser AJ, Brenkel IJ, Irvine GB. Articular fractures of the distal scaphoid. J Hand Surg Br 1988;13(1):87-91.

26. Compson JP. The anatomy of acute scaphoid fractures: a three-dimensional analysis of patterns. J Bone Joint Surg Br 1998;80(2):218-24.

27. Desai W, Davis TR, Barton NJ. The prognostic value and reproducibility of the radiological features of the fractured scaphoid. J Hand Surg Br 1999;24(5):586-90.

28. Buijze GA, Doornberg JN, Ham JS, Ring D, Bhandari $M$, Poolman RW. Surgical compared with conservative treatment for acute nondisplaced or minimally displaced scaphoid fractures. A systematic review and meta-analysis of randomized controlled trials. J Bone Joint Surg Am 2010;92(6):1534-44. CrossRef

29. Bhat M, McCarthy M, Davis TR, Oni JA, Dawson S. MRI and plain radiography in the assessment of displaced fractures of the waist of the carpal scaphoid. J Bone Joint Surg $\mathrm{Br}$ 2004;86(5):705-13.

30. LanghoffO, Andersen JL. Consequences of late immobilization of scaphoid fractures. J Hand Surg Br 1988;13(1):77-9.

31. Slade JF 3rd, Gutow AP, Geissler WB. Percutaneous internal fixation of scaphoid fractures via an arthroscopically assisted dorsal approach. J Bone Joint Surg Am 2002;84-A Suppl 2:21-36.

32. Kawamura K, Chung KC. Treatment of scaphoid fractures and nonunions. J Hand Surg Am 2008;33(6):988-97. CrossRef

33. Dias JJ, Wilson CJ, Bhowal B, Thompson JR. Should acute scaphoid fractures be fixed? A randomized controlled trial. J Bone Joint Surg Am 2005;87(10):2160-8.

34. Dias JJ, Taylor M, Thompson J, Brenkel IJ, Gregg PJ. Radiographic signs of union of scaphoid fractures. An analysis of inter-observer agreement and reproducibility. J Hand Surg Br 1988;70(2):299-301.

35. Herbert TJ, Fisher WE, Leicester AW. The Herbert bone screw: a ten year perspective. J Hand Surg Br 1992;17(4):415-9.

36. Krimmer $\mathrm{H}$. Management of acute fractures and nonunions of the proximal pole of the scaphoid. J Hand Surg Br 2002 27(3):245-8.

37. Barton NJ. Twenty questions about scaphoid fractures. J Hand Surg Br 1992;17(3):289-310.
38. Rettig ME, Raskin KB. Retrograde compression screw fixation of acute proximal pole scaphoid fractures. J Hand Surg Am 1999;24(6):1206-10.

39. Gellman H, Caputo RJ, Carter V, Aboulafia A, McKay M. Comparison of short and long thumb-spica casts for nondisplaced fractures of the carpal scaphoid. J Bone Joint Surg Am 1989;71(3):354-7.

40. Vinnars B, Pietreanu M, Bodestedt A, Ekenstam F, Gerdin. Nonoperative compared with operative treatment of acute scaphoid fractures. A randomized clinical trial. J Bone Joint Surg Am 2008;90(6);1176-85. CrossRef

41. Schramm JM, Nguyen M, Wongworawat MD, Kjellin I. Does thumb Immobilization contribute to scaphoid fracture stability? Hand (N.Y.) 2008;3(1):41-3. CrossRef

42. Kaneshiro SA, Failla JM, Tashman S. Scaphoid fracture displacement with forearm rotation in a shortarm thumb spica cast. J Hand Surg Am 1999;24(5):984-91.

43. Dao KD, Shin AY. Percutaneous cannulated screw fixation of acute nondisplaced scaphoid waist fractures. Operative Techniques in Orthopaedics, 2003;13(1):11-20. CrossRef

44. Haddad FS, Goddard NJ. Acute percutaneous scaphoid fixation . A pilot study. J Bone Joint Surg Br 1998;80(1):95-9.

45. Slade JF, Grauer JN, Mahoney JD. Arthroscopic reduction and percutaneous fixation of scaphoid fractures with a novel dorsal technique. Orthop Clin North Am 2001;32(2):247-61.

46. Bond CD, Shin AY, McBride MT, Dao KD. Percutaneous screw fixation or cast immobilization for nondisplaced scaphoid fractures. J Bone Joint Surg Am 2001;83-A(4):483-8.

47. Trumble TE, Gilbert M, Murray LW, Smith J, Rafijah G, McCallister WV. Displaced scaphoid fractures treated with open reduction and internal fixation with a cannulated screw. J Bone Joint Surg Am 2000;82(5):633-41.

48. Heinzelmann AD, Archer G, Bindra RR. Anthropometry of the human scaphoid. J Hand Surg Am 2007;32(7):1005-8.

49. McCallister WV, Knight J, Kaliappan R, Trumble TE. Central placement of the screw in simulated fractures of the scaphoid waist: a biomechanical study. J Bone Joint Surg Am 2003;85-A(1):72-7.

50. Trumble TE, Clarke T, Kreder HJ. Non-union of the scaphoid. Treatment with cannulated screws compared with treatment with Herbert screws. J Bone Joint Surg Am 1996;78(12):1829-37.

51. Oduwole KO, Cichy B, Dillon JP, Wilson J, O'Beirne J. Acutrak versus Herbert screw fixation for scaphoid nonunion and delayed union. J Orthop Surg (Hong Kong) 2012;20(1):61-5.

52. Wheeler DL, McLoughlin SW. Biomechanical assessment of compression screws. Clin Orthop Relat Res 1998;(350):237-45.

53. Merrell G, Slade J. Technique for percutaneous fixation of displaced and nondisplaced acute scaphoid fractures and select nonunions. J Hand Surg Am 2008;33(6):966-73. CrossRef

54. Geissler WB, Adams JE, Bindra RR, Lanzinger WD, Slutsky DJ. Scaphoid fractures: what's hot, what's not. J Bone Joint Surg Am 2012;94(2):169-81. CrossRef

55. Shih JT, Lee HM, Hou YT, Tan CM. Results of arthroscopic reduction and percutaneous fixation for acute displaced scaphoid fractures. Arthroscopy 2005; 21(5):620-6.

56. Mody BS, Belliappa PP, Dias JJ, Barton NJ. Nonunion of fractures of the scaphoid tuberosity. J Bone Joint Surg $\mathrm{Br}$ 1993;75(3):423-5. 